\title{
Pesticides and Their Movement Surface Water and Ground Water
}

\author{
Feza Geyikçi \\ Ondokuz Mayus University, Chemical Engineering Department, \\ Turkey
}

\section{Introduction}

Pesticides are poisons designed to kill pests such as rodents, insects, weeds and fungi. Pesticides are, by their nature, toxic chemicals; since many pesticides may potentially leave residues on foods available for human consumption, there is much concern regarding the potential health risks of pesticides in the human diet. Pesticides used in agriculture to control pests, such as insects, weeds, and plant diseases, have been subject to considerable legislative, regulatory, and consumer scrutiny over the past few decades. Pesticides, with their high degree of toxicity, constitute a very important group of target compounds in environmental samples. Those presentnin waters may have an agricultural, domestic or industrial origin, the most harmful effect being their inclusion in the so-called "nutritionchain" (Vinas et al., 2002). Many common pesticides contain potent neurotoxic chemicals that attack and disable portions of the nervous system and brain. The use of pesticides in commercial agriculture has led to an increase in farm productivity (Guler et al., 2010). Pesticides also present environmental concerns including water and soil contamination, air pollution, destruction of natural vegetation, reductions in natural pest populations, effects upon non-target organisms including fish, wildlife, and livestock, creation of secondary pest problems, and the evolution of pesticide resistance (Winter, 2004). Many pesticides were used on a global scale from the 1950s to the mid-80s, most of which are stable and persistent in the environment (Barra et al., 2001).

The use of pesticides in agriculture is necessary to combat a variety of pests that could destroy crops and to improve the quality of the food produced. The advantages and disadvantages of pesticide pollution controlling technique are determined by many factors, which require a comprehensive evaluation method adopted in the evaluation of pesticide pollution controlling techniques. Exposure to high levels of pesticides can cause a range of acute, flu- and malaria-like symptoms including headaches, weakness, nausea, respiratory distress, convulsions, coma, and death, accounting for an estimated 20,000 fatalities per year (Jiang and Wan, 2009; Guler et al., 2010).

In a recent USEPA summary report defined vulnerability applied to risk assessment as a four component system: (1) susceptibility or sensitivity of the human or ecological receptors; (2) differential exposures of the receptors; (3) differential preparedness of the receptor to withstand the insult from exposure; (4) differential ability to recover from these effects. All of these components are pertinent to systems undergoing development from the fetus 
through childhood. For example, differences in the chemical biotransformation capacity of the human fetus and developing child can be both protective and potentially detrimental to normal development Regarding this point, there is little direct information regarding the specific metabolism of xenobiotics, much less pesticides, in children or the fetus. Overriding differences in biotransformation in the fetus is the probable role of maternal metabolism of xenobiotics affecting the level of fetal toxicant exposure. Polymorphisms of maternal phase 1 and phase 2 enzymes may play a key role in these exposure events (Garry, 2004).

Deterioration of surface and ground water quality represent the most significant adverse environmental impact associated with agricultural production. Degradation of surface and ground water quality has been identified as the primary concern with respect to the impact of agriculture on the environment. The degradation may occur as a result of the leaching of agricultural chemicals soil or biological organisms to surface waters. In this study, it is evaluated the surface and ground water contamination by pesticides.

\section{Pesticide properties}

The physical and chemical properties that make pesticides effective for pest control also create a potential for surface and ground-water contamination. The fate of a pesticide applied to soil depends largely on two of its properties: persistence and adsorption (adsorption is inversely related to solubility). Persistence is the "lasting power" of a pesticide. Most pesticides in the soil break down or "degrade" over time as a result of several chemical and microbiological reactions.

Generally, chemical reactions result in only partial deactivation of pesticides whereas soil microorganisms can completely break down many pesticides to carbon dioxide, water and other inorganic constituents. Some pesticides produce intermediate substances called metabolites as they degrade. The biological activity of these substances may or may not have environmental significance. Microbes decrease rapidly below the root zone so pesticides leached below this depth are less likely to be microbially degraded. However, some pesticides will continue to degrade by chemical reactions after they have left the root zone.

Degradation time is measured in half-life. Half-life refers to the amount of time it takes for a pesticide in soil to reach half the activity level it had at the time of application (i. e., for a pesticide with a half-life of 30 days, 50 percent of the pesticide will have degraded after 30 day). Pesticides having short half-lives often do not persist in the soil long enough to leach into groundwater. Chemicals with long half-lives are highly persistent and have a greater change of leaching into groundwater. To describe potential persistence, scientists classify pesticides as follows:

1. Non-persistent chemicals

2. Moderately persistent chemicals

3. Persistent chemicals 1997).

Half-life less than 30 days

Half-life of 30 to 100 days

Half-life greater than 100 days (Mahler et al.,

Pesticides are divided into many classes. The pesticide classes are shown in Table 1(Squibb, 2002). The adsorption process binds pesticides to soil particles, like iron fillings or paper clips stick to a magnet. Adsorption occurs because of the attraction between chemicals and soil particles. Pesticide molecules are positively charged. For example, are attracted to and can bind to negatively charged clay particles. Strongly adsorbed pesticides are less subject to through soil than weakly adsorbed pesticides. On the other hand, strongly adsorbed pesticides are more subject to loss via surface runoff. Factors controlling pesticides 


\begin{tabular}{|c|c|c|}
\hline Group & Subgroups & Examples \\
\hline (n) & & $\begin{array}{l}\text { DDT } \\
\text { Endrin } \\
\text { Aldrin } \\
\text { Dieldin } \\
\text { Endosulfan } \\
\text { a-, } \beta-, \gamma^{-}, \\
\text {Hexachlorocyclohexane }\end{array}$ \\
\hline Anticholinesterases & $\begin{array}{l}\text { Organophophates (Ops) } \\
\text { Carbamates }\end{array}$ & $\begin{array}{l}\text { Malathion } \\
\text { Fenitrothion } \\
\text { Dichlorvos } \\
\text { Diazinon } \\
\text { Carbaryl } \\
\text { Aldicarb }\end{array}$ \\
\hline Pyrethrins and synthetic & & \\
\hline Pyrethroids & & $\begin{array}{l}\text { Pyrethrum } \\
\text { Permethrin } \\
\text { Cypermethrin } \\
\text { Flumethrin }\end{array}$ \\
\hline $\begin{array}{l}\text { Natural compounds, other } \\
\text { than pyrethrins }\end{array}$ & Juvenile hormone analogues & $\begin{array}{l}\text { Abamectin } \\
\text { Ivermectin } \\
\text { Rotatone } \\
\text { Nicotine }\end{array}$ \\
\hline $\begin{array}{l}\text { Substances which interfere } \\
\text { with system } \\
\text { specific to insect }\end{array}$ & $\begin{array}{l}\text { Chitin synthesis inhibitors } \\
\text { Ecdysone agonists }\end{array}$ & $\begin{array}{l}\text { Cyromazine } \\
\text { Diflubenziron } \\
\text { Tebufenozite }\end{array}$ \\
\hline $\begin{array}{l}\text { Miscellanous synthetic } \\
\text { insecticides }\end{array}$ & $\begin{array}{l}\text { Formamidine } \\
\text { GABA }_{\mathrm{A}} \text { blocker }\end{array}$ & $\begin{array}{l}\text { Amitraz } \\
\text { Fibronil }\end{array}$ \\
\hline
\end{tabular}

Table 1. The Main classes of Pesticides

adsorption include pesticide charge; soil $\mathrm{pH}$, temperature and water content; the presence of previously adsorbed chemicals that have a stronger bond to soil particles; and the amount and type of organic matter present. In general, pesticide adsorption relates inversely to pesticide solubility in water. Highly soluble pesticides are weakly adsorbed and pose a greater threat of groundwater contamination.

Four chemical properties that affect pesticide movement are solubility, adsorption, volatility and degradation.

Solubility: The tendency of a pesticide to dissolve in water affects its leaching potential. As water seeps downward through soil, it carries with it water- soluble chemicals. This process is called leaching. Water solubility greater than $30 \mathrm{mg} / \mathrm{L}$ has been identified as the flag for a 
potential leached. Highly soluble pesticides have a tendency to be carried in surface runoff and to be leached from the soil to groundwater. Poorly soluble pesticides applied to soil but not incorporated have a high potential for loss through runoff or erosion.

Adsorption: Adsorption refers to the attraction between a chemical and soil particles. Many pesticides do not leach because they are adsorbed, or tightly held by soil particles. Pesticides which are weakly adsorbed will leach in varying degrees depending on their solubility. Adsorption depends not only on the chemical properties of the pesticide but also on the soil type and amount of soil organic matter present. Even strongly adsorbed pesticides can be carried with eroded soil particles in surface runoff. The potential for a pesticide to be adsorbed is called the adsorption partition coefficient $\left(\mathrm{K}_{\mathrm{d}}\right)$. The lower the partition coefficient is the greater the pesticide leaching potential.

Volatility: The tendency of a pesticide to become a gas, similar to the evaporation of water will affect its loss to the atmosphere by volatilization. If a pesticide is highly volatile (has a high vapour pressure) and is not very water soluble, it is likely to be lost to the atmosphere and less will be available for leaching to groundwater. Highly volatile compounds may be come groundwater contaminants, however if they are highly soluble in water. For most pesticides, loss through volatilization is insignificant compared with leaching or surface losses. Volatile pesticides may cause water contamination or other problems from aerial drift. Environmental conditions such as temperature, humidity and wind speed affect volatilization losses. Special surfactants or carriers can be used to reduce volatilization losses.

Degradation: A pesticides rate of degradation (persistence) in soil also affects leaching potential. Pesticides are degraded or broken down into other chemical forms by sunlight (photodecomposition) by microorganisms in the soil and by a variety of chemical and physical reactions. The longer the compound lasts before it is broken down that is the longer it persist the longer it is subject to the forces of leaching and runoff (Hairston, 1995).

\section{Pesticide movement in surface water and ground water}

For an agricultural system to be sustainable, adverse environmental effects of agricultural production must be minimized while competitiveness and profitability are maintained or enhanced. Degradation of surface and ground water quality has been identified as the primary concern with respect to the impact of agriculture on the environment. The degradation may occur as a result of the leaching of agricultural chemicals soil or biological organisms to surface waters. Contamination of surface water is less serious than is the case for groundwater. Properly applied pesticides may reach surface water and groundwater in three basic ways: runoff, run-in, and leaching. Runoff is the physical transport of pollutants over the soil surface by rainwater that does not soak into the soil. Pesticides move from fields while dissolved or suspended in runoff water or adsorbed (chemically attached) to eroded sediment. Run-in is the physical transport of pollutants directly to groundwater. For example, this can occur in areas of limestone (Karst-carbonate) aquifers, which contain sinkholes and porous or fractured bedrock. Rain or irrigation water can carry pesticides through sinkholes or fractured bedrock directly into groundwater. Leaching is the movement of pollutants through the soil by rain or irrigation water as the water moves downward through the soil. Soil organic matter content, clay content and permeability all affect the potential for pesticides to leach in soils. In general, soils with moderate to high organic matter and clay content and moderate or slow permeability are less likely to leach 
pesticides into groundwater. In fine textured soils, macropores, which are principally root channels and wormholes, may contribute to the leaching of pesticides.

The advantages and disadvantages of pesticide pollution controlling technique are determined by many factors, which require a comprehensive evaluation method adopted in the evaluation of pesticide pollution controlling techniques. But in the average comparison experiment of pesticide pollution controlling techniques, an intuitive analysis and simple nature description of the ecologic, economic factors under the technique effects are made and the analysis results are independent to each other, a systematic and comprehensive evaluation of advantages and disadvantages of candidate techniques compared is difficult to be made. The change and development of these factors themselves is a grey change process. The Grey System Theory put forward by Deng Julong in 1980s is a new method of solving problems of few data, poor information and uncertainty, which takes the systems of "small sample", "poor information" and "uncertainty" with part information known and part unknown as the subject, mainly by finding valuable information through creation and development from the "part" information known, so as to achieve correct description and effective monitoring of rules of the system operation and evolution. At present, the Grey System Theory is widely applied in many scientific fields, but no literatures of pesticide pollution controlling evaluation can be found. During the pesticide pollution controlling evaluation, the information provided by limit system investigation and spatial-temporal detection data is not complete and certain and the vegetable field pesticide controlling system is a grey system. Based on this point, this paper has made a comprehensive comparison of the pesticide pollution controlling techniques in the vegetable production by adopting a relational analysis method of the Grey System Theory. The chemical pesticide provides a necessary guarantee for the output increase, but the pesticide abuse has led to daily worsen of the ecosystem of agricultural fields (Jiang et al., 2009).

\subsection{Pesticides in groundwater}

Pesticides in groundwater are an extremely serious problem. The turnover rate for groundwater may be as a few months, but more commonly years and decades are needed to replace the water in an oxygen-free environment are much less effective in breaking down pesticide chemicals. Extremely slow dilution and breakdown means that the contaminant will be present for a long time. The most critical hazard of contaminated groundwater is the potential for toxic effects in man and domestic animals that drink the water. Contamination of an underground aquifer cannot be easily corrected. Doing so requires drilling purge wells and pumping the water to the surface. Pumping may have to be continued for a long time to remove all the contaminated water. The process is extremely expensive. Preventing groundwater contamination is the best solution to what could be a hazardous situation. Numerous instances of groundwater contaminated with pesticides have been identified. In some cases, small communities have had to use bottled water until other sources of drinking water were developed. At this time, the full extent of groundwater contamination is not known. Pesticides have been found in groundwater in numerous instances, however, and it seems apparent that more instances will be discovered as more and more underground aquifers are sampled and tested for the presence of pesticides. The time it takes for pesticides to travel to groundwater decreases as the depth to groundwater decreases. Generally, the depth to groundwater is least in spring and greatest in late summer. If spring rains come shortly after pesticide application and water table is close to the surface, a greater potential for groundwater contamination exists. 


\subsection{Pesticides in surface water}

The presence of pesticides in surface water, even in very small amounts, compromises the life cycle of aquatic organisms, such as algae and fish (tumors, interference with hormonal systems, respiration, growth, reproduction, etc.). Pesticides are harmful to the environment and a threat to the health of those who use these substances, notably those working in the agriculture (headaches, fertility loss, carcinogenic effect, etc.). But most importantly, the prolonged consumption of drinking water, fruits, and vegetables containing pesticides, even at very low doses, presents long-term risks to health. The question of pesticides brings up particular concerns in the area of drinking water production and wastewater treatment because these are among the principal pollutants that impact water resources.Surface water also can be contaminated directly by pesticide spray drift the travel and deposition of fine pesticide spray droplets away from their intended target when the spray is applied too close to water. Drift incidents can result in greater surface water contamination than either runoff or leaching. Obvious, acute effects such as fish kills can occur. Most surface waters (except deep lakes) have a rapid turnover rate, which means that fresh water dilutes the concentration of the contaminant quickly. In addition, most surface waters contain free oxygen, which enhances the rate at which pesticides are broken down by microorganisms. Contamination of surface waters should not be treated casually. An extremely toxic pesticide can cause the death of fish and other aquatic organisms even at low concentrations. Rivers and streams are receptors of toxic wastes generated on land. Pesticides impair beneficial uses of these waters and their biological resources. Pesticides are a group of organic compounds which have been found in aquatic systems worldwide (Rovedatti et al., 2001).

\section{Pesticide transport in air, water and soil}

In structured soils, macropore flow often causes rapid nonuniform leaching via preferential flow paths, where a fraction of the contaminant percolates into ground water before it can degrade or be adsorbed by the soil. As a result of agricultural practices, pesticides have been detected in many aquifers and surface waters. With regard to pesticides, moderately sorbed compounds with relatively short half-lives are particularly affected. Travel times for pesticides preferentially leached below the root zone are comparable to those for conservative solutes, with losses of typically less than $1 \%$ of the applied dose, but reaching up to $5 \%$ of the applied mass. These apparently small numbers can be put into perspective by considering the EU drinking water standard, which states that concentrations of a single pesticide may not exceed $0.1 \mu \mathrm{g} \mathrm{l}^{-1}$. For a dose of $0.2 \mathrm{~kg} \mathrm{ha}^{-1}$ and an annual recharge of 200 $\mathrm{mm}$, this implies a maximum allowed leaching loss of only $0.1 \%$ of the applied amount. Hence, macropore flow should be considered in risk assessment of ground water contamination with pesticides. Pesticide leaching through the vadose zone to ground water is a complex process controlled by a range of soil and environmental conditions.

Accordingly, pesticide fate models account for a variety of processes including soil water flow, solute transport, heat transport, pesticide sorption, transformation and degradation, volatilization, crop uptake, and surface runoff. A particular modeling challenge is to predict pesticide transport at very low leaching levels important for pesticide registration. On the other hand, it has been argued that for very low concentrations, approaching the level of quantification, the criteria for accuracy need not be as rigorous, particularly when the analysis takes into account the uncertainty of data and model outcome. 


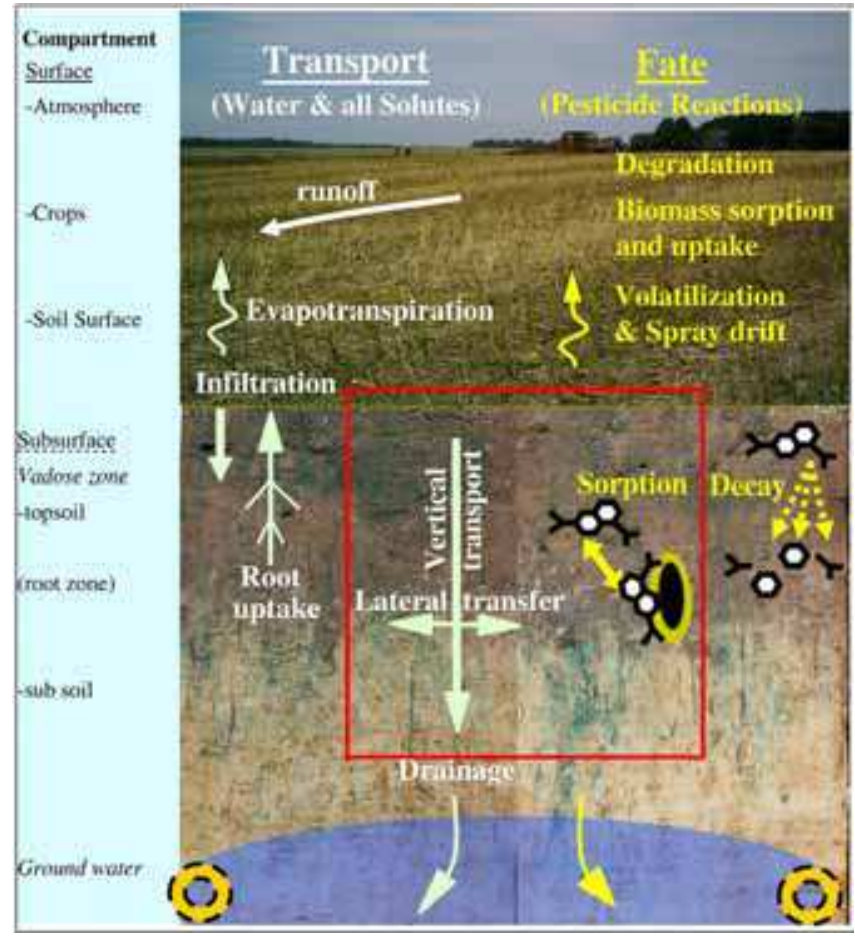

Fig. 1. Principal processes governing pesticide transport and fate in agricultural structured soil systems. The central frame is explained in Fig. 2.

The principal processes governing pesticide transport and fate in agricultural structured soil systems are illustrated in Fig. 1. Soil matrix and macropore characteristics invoking different transport patterns are highlighted in Fig. 2. Descriptions of models for simulating transport of pesticides (and other chemicals) can be found in several reviews and model comparison studies (Colume et al., 2001; Köhne et al., 2009).

Once applied to cropland, a pesticide may be taken up by plants, adsorbed to plant surfaces, broken down by sunlight (photodegradation), or ingested by animals, insect, worms or microorganisms in the soil. It may be downward in the soil and either adhere to soil particles or dissolve in soil water. The pesticide may be vaporize and enter the atmosphere (volatization) or breakdown via microbial and chemical pathways into less toxic compounds. Pesticides may be leached out of the root zone by rain or irrigation water or wash off the surface of the land. Pesticides applied to the soil and immediately incorporated are protected from photodegradation, volatization and dew, which can cause hydrolysis (decomposition by reaction with water). Properly applied pesticides can reach surface and under-ground waters in two ways: in runoff and by leaching. Runoff is the physical transport of pollutants (chemical or soil) over the ground surface by rainwater, snowmelt or irrigation water that does not penetrate the soil. In the leaching process, pollutants are carried through the soil by rain or irrigation water as it moves downward. 


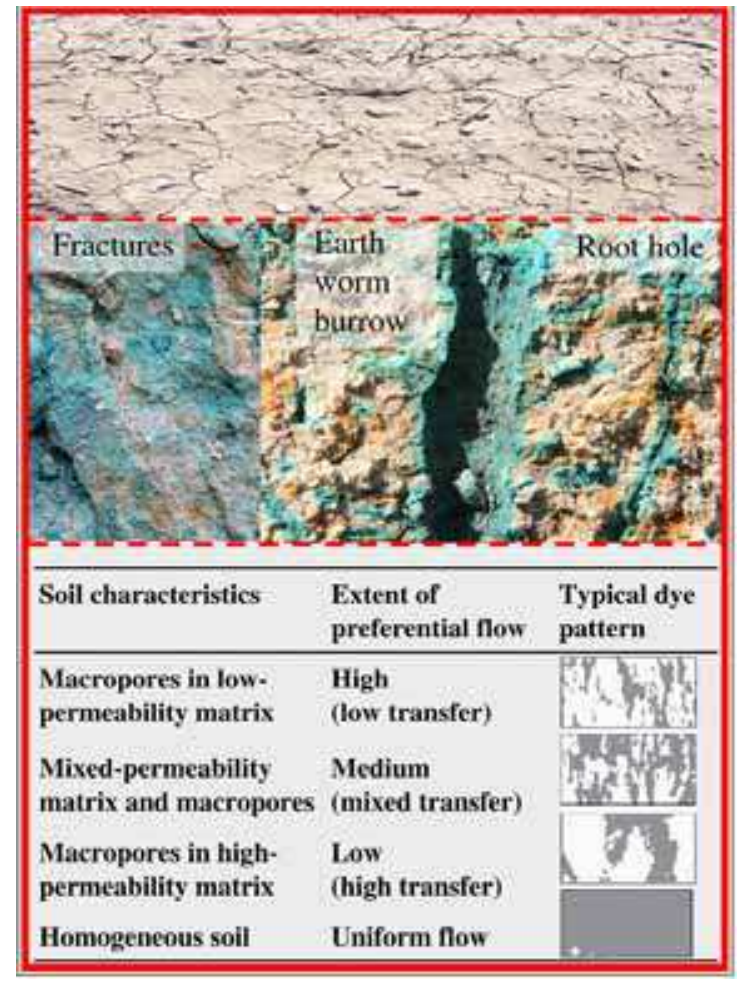

Fig. 2. Fractures and microtopography are triggers for preferential infiltration (top), Diverse structure/matrix interfaces stained by dye tracer visualize different preferential transport paths; these interfaces may affect lateral diffusion, sorption and degradation (middle). Soil matrix and macropore characteristics and resulting transport patterns; actual patterns also depend on the characteristics of rainfall and of overlaying soil horizons

\subsection{Factors affecting pesticide movement}

Pesticides are primarily moved from agricultural fields to surface waters in surface run-off. The amount lost from fields and transported to surface waters depends on several factors, including soil characteristics, topography, weather, agricultural practices, and chemical and environmental properties of individual pesticides (Colume et al., 2001). Pesticides that are susceptible to leaching do not move through all soils and into ground water at the same rate. Leaching and runoff are nonpoint pollution processes that depend on five sets of factors, some of which are controllable and some not.

1. Application factors: These include the application site (crop or weed plants or soil surface or subsurface), the formulation (e. g., granules or suspended powder or liquid), and the application amount and frequency). The management practices that affect movement of pesticides are application methods, application rates and timing, and handling practices. The way in which a pesticide is applied determines leaching potential. Injection or incorporation into the soil, as in the case of nematocides, makes the pesticide most readily available for leaching. Most of the pesticides which have been 
detected in groundwater are those which are incorporated into the soil rather than sprayed onto growing crops. Pesticides sprayed onto crops, however are more susceptible to volatilization and surface runoff losses. Application rates and timing of a pesticides application also are critical in determining whether it will leach to groundwater. The larger the amount used and the closer the time of application to a heavy rainfall or irrigation, the more likely that some pesticide will leach to groundwater. Particular care should be taken when practicining chemigation because of the risks of back-siphoning and leaching. Properly storing and mixing pesticides and properly disposing of the containers are other factors that can contribute significantly to the contamination of surface water or groundwater. Quick and proper cleanup of spills is also important.

2. Pesticide persistence and mobility: Some pesticide-soil combinations result in such strong binding of the pesticide to soil particles that the pesticide is moved only if the soil is moved, i. e., if erosion occurs. Many pesticides now in use are degraded so quickly on soil and crop surfaces that rainfall must occur within a few days after application for significant transport to occur. Pesticides must be relatively persistent and mobile to leach to ground water because the travel time for water to percolate to deep aquifers can range from months to years. However, once a pesticide has leached into subsurface soils, the biological activity and binding capacity there are often less than in soils near the surface. Thus, the pesticide becomes more persistent and mobile. Persistent and mobile pesticides also are more a threat for runoff. However, that part of pesticide residues which is most available for runoff -the part at the topmost surface of soils is the part most rapidly dissipated by evaporation and photodegradation. Moreover, runoff transport can be complete in hours, and erosion can transport immobile pesticides attached to soil. Thus, pesticide runoff is less dependent on the pesticide properties than pesticide leaching, and much more dependent on how soon runoff occurs after application.

3. Soil and field topography: Soils differ greatly in their capacity to absorb water. The slope and drainage pattern of a field or a watershed greatly affect its potential to generate runoff water. Fast-draining soils such as sands and sandy loams have the greatest leaching potential; slow-draining clays and silty clays have the greatest runoff potential. Watershed size has an important effect on runoff pesticide concentration patterns; small streams adjacent to treated fields can have very high peak concentrations of hundred of $\mathrm{ppb}$, but concentrations decrease quickly to low values. In large rivers, peak concentrations are much lower but concentrations may be elevated longer. The properties of soils that affect pesticide movement are texture, permeability and organic matter content. Soil texture is determined by relative proportions of sand, silt and clay. Texture affects movement of water through soil (infiltration) and therefore, movement of dissolved chemicals such as pesticides. The sandier the greater the change of a pesticide reaching groundwater. Coarse- textured sands and gravels have high infiltration capacities and water tends to percolate through the soil rather than to runoff over the soil surface or be adsorbed to soil particles. Therefore, coarsetextured soils generally have high potential for leaching of pesticides to groundwater but low potential for surface loss to streams and lakes. On the other hand, fine-textured soils such as clays and clay loams generally have low infiltration capacities and water tends to runoff rather than to percolate. Soils with more clay and organic matter also have more surface area for adsorption of pesticides and higher populations of 
microorganisms to breakdown pesticides. Therefore, fine-textured soils have low potential for leaching of pesticides to groundwater and high potential for pesticide surface loss. Highly permeable soils are susceptible to leaching. Soil permeability is a measure of how fast water can move downward through a particular soil and can typically be inferred from soil texture. Since water moves quickly through highly permeable soils, these soils may lose dissolved chemicals with the percolating water. In highly permeable soil, the timing and the method of pesticide application need to be carefully designed to minimize leaching losses. Soils high in organic matter have a low leaching potential. Soil organic matter influences how much water a soil can hold and how well it will be able to adsorb pesticides and prevent their movement. In addition, high organic matter may reduce potential for surface loss by increasing the soils ability to hold both water and dissolved pesticides in thr root zone where they will be available to plants. High organic matter also supports much of the microbial activity that decomposes pesticides.

4. Weather and climate: Climate affects the type of grown, the intensity of pest problems, and the persistence of pesticides used. The intensity of rainfall and its timing with respect to pesticide application determines how much pesticide transport occurs. While these factors are not controllable, probabilities of pesticide runoff and leaching can be estimated, and avoiding pesticide application when rain is imminent is often possible. Areas with high rates of rainfall or irrigation may have large amounts of water percolating through the soil and therefore, are highly susceptible to leaching of pesticides especially if the soils are highly permeable. Intensity, duration and frequency of occurrence of rainfall also affect storm water runoff and losses of surface- applied pesticides.

5. Farm management: Pesticides manufacturers are making an effort to provide farmers with the information needed for pollution prevention. The farmer has considerable control over the pollution probabilities: knowledge of erosion control and of best application techniques, and an eye on the weather, is the first lines of defence against pollution (Wauchope et al., 1994; Vinas et al., 2002).

\subsection{Methods of prevention}

Farm pesticides are regulated by state and federal laws. It can be held liable for any damage to people, animals, fish, or wildlife resulting from your pesticide use and handling practices. Protect and the environment by using pesticides on labelled crops at label rates. Safely store and transport pesticides and all potential pollutants to reduce the chance of an accident or spill. This can be accomplished by following two basic steps.

1. Select the proper chemical for the pest to be controlled. Identify the pest by pictures and descriptions in publications available from agricultural agencies, public libraries or local garden centres. Select only a pesticide that is recommended both for the pest and the plant or location affected.

2. After deciding on the pesticide formulation and appropriate application method, thoroughly read, understand and follow label directions.

Pesticide users should be aware of several specific situations when analyzing their pesticide use practices in the context of potential groundwater contamination. All need to be carefully considered. Correcting one bad practice will not help when another bad practice may represent a bigger problem.

Storage: Checking storage facilities should be first step in the chain of events involved with pesticide use. Containers are frequently opened in the storage area and the possibility of a 
spill cannot be ignored. Spilling a concentrated formulation is a more serious matter than applying diluted material on a field. Storage facilities should have a concrete floor so that spilled concentrate can be cleaned up and disposed of properly thereby avoiding soil and water contamination.

Mixing and loading: Mixing and loading sites are areas where a lot of pesticide can be inadvertently spilled on the ground. Repeated spills increase the concentration of the pesticide in the soil and increase the possibility of materials leaching through the soil to groundwater. Growers who apply a lot of pesticide should construct a pit lined with clay or preferably concrete and filled with rock and soil. Mixing and loading can be carried out over the pit so that any spill is contained and the active ingredient is broken down without the possibility of leaching to groundwater. The pit must be large enough to accommodate the maximum pesticide use anticipated for an operation. Many commercial pesticide applicators now have such a pit, which is often covered with a concrete slab sloped toward a drain in the centre that provides access to the pit.

Application: Multiple applications to the same area have been responsible for groundwater contamination in several locations in the growers who depend on multiple pesticide applications for a crop should be analyze their pest management practices carefully with a view toward reducing the number of applications, the total amount applied, using a different pesticide less likely to leach through the soil profile, or using nonchemical methods to manage the pests. The problem is particularly acute when applications are made to sandy soil in areas with a high water table. Growers in such a situation will want to enlist help of pest management specialists in order to design a program that minimizes the possibility of groundwater contamination without sacrificing effective pest control.

Rinsing tanks: Rinsing spray tanks can be a source of possible contamination. The best solution is to drain rinse water into a pit, as described in the section on mixing and loading. If no pit is available, users should not dump or spray the rinse water in the same place repeatedly. Always remember that the more pesticide applied to the same area, the greater the possibility of the active ingredient leaching to groundwater. It is also important to calculate accurately the amount of spray solution needed to avoid the need for disposing of excess spray solution.

Rinsing and disposing of containers: Rinsing and disposing of containers is the last in the sequence of operations involved in the use of pesticides. A container is never completely empty and the concentrated formulation remaining represents a troublesome source of future contamination. Containers should be rinsed three times with the rinsate being added to the spray solution and then punctured so they can't be used for another purpose and disposed of in a sanitary landfill. Some landfill operators will not accept the containers unless they are crushed so they will take up less space in the landfill. Paper or cardboard containers should be emptied as completely as possible then punctured and disposed of in landfill. The pesticides are never completely combusted and represent a potentially hazardous source of exposure for the person doing the burning (Noyes et al., 1991; Wauchope et al., 1994).

\section{References}

Barra R.; Cisternas M.; Urrutia R.; Pozo K.; Pacheco P.; Parra O.; Focarti S. (2001). First report on chlorinated pesticide deposition in a sediment core from a small lake in central Chile, Chemosphere, Vol. 45, pp. 749-757. 
Columé A.; Cardenas S.; Gallego M.; Vascarcel M. (2001). Evaluation of an automated solidphase extraction system fort he enrichment of organochlorine pesticides from waters. Talanta, Vol. 54, pp. 943-951.

Garry V.F. (2004). Pesticides and children, Toxicology and Applied Pharmacology, Vol.198, pp. $152-163$.

Guler G.O.; Cakmak Y.S.; Dagli Z.; Aktumsek A.; Ozparlak H. (2010). Organochlorine pesticide residues in wheat from Konya region, Turkey, Food and Chemical Toxicology, Vol.48, pp. 1218-1221.

Hairston J.E. (1995). Pesticide management to protect water quality understanding pesticides and how they affect water quality. Water Quality and Pollution Control Handbook, ANR-790, Section: 4.5.1.

Jiang J.; Wan N. (2009). A model for ecological assessement to pesticide pollution management, Ecological Modelling, Vol.220, pp. 1844-1851.

Köhne J.M.; Köhne S.; Šimůnek J. (2009). A review of model applications for structured soils: b) Pesticide transport, eburnal of Contaminant Hydrology, Vol.104, pp. 36-60.

Mahler R.; Homan H.W.; Carpenter G.P. (1997). Pesticides and their movement in soil and water. http://www.uidaho.edu/wq/wqpubs/cis865.html

Rovedatti M.G.; Castane P.M.; Topalian M.L.; Salibian A. (2001). Monitoring of organochlorine and organophosphorus pesticides in the water of the Reconquista river (Buenos Aires, Argentina). Water Resources, Vol. 35, pp. 3457-3461.

Squibb K. (2002). Program in Toxicology, Applied Toxicology, NURS 678.

Vinas P.; Campillo N.; Garcia L.; Aguinaga N.; Cordoba M.H. (2002). Determination of pesticides in waters by capillary gas chromatography with atomic emission detection. eburnal of Chromatography A, Vol. 978, pp. 249-256.

Wauchope R.D.; Baker D.B.; Balu K.; Nelson H. (1994). Pesticides in surface and ground water. Council for Agricultural Science and Technology, Number 2, cast@castscience.org.

Winter C.K. (2004). Surveillance for pesticides residues, University of California, Woodhead Publishing Limited, Davis, USA.

Noyes R.T.; Norris P.E.; Criswell J.T. (1991). Rinsing and disposing of pesticide containers. http://osufacts.okstate.edu. 


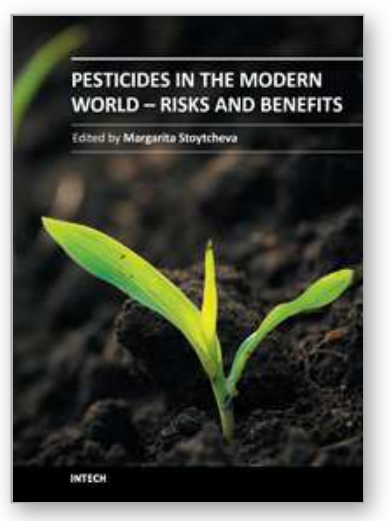

\author{
Pesticides in the Modern World - Risks and Benefits \\ Edited by Dr. Margarita Stoytcheva
}

ISBN 978-953-307-458-0

Hard cover, 560 pages

Publisher InTech

Published online 03, October, 2011

Published in print edition October, 2011

This book is a compilation of 29 chapters focused on: pesticides and food production, environmental effects of pesticides, and pesticides mobility, transport and fate. The first book section addresses the benefits of the pest control for crop protection and food supply increasing, and the associated risks of food contamination. The second book section is dedicated to the effects of pesticides on the non-target organisms and the environment such as: effects involving pollinators, effects on nutrient cycling in ecosystems, effects on soil erosion, structure and fertility, effects on water quality, and pesticides resistance development. The third book section furnishes numerous data contributing to the better understanding of the pesticides mobility, transport and fate. The addressed in this book issues should attract the public concern to support rational decisions to pesticides use.

\title{
How to reference
}

In order to correctly reference this scholarly work, feel free to copy and paste the following:

Feza Geyikçi (2011). Pesticides and Their Movement Surface Water and Ground Water, Pesticides in the Modern World - Risks and Benefits, Dr. Margarita Stoytcheva (Ed.), ISBN: 978-953-307-458-0, InTech, Available from: http://www.intechopen.com/books/pesticides-in-the-modern-world-risks-andbenefits/pesticides-and-their-movement-surface-water-and-ground-water

\section{INTECH}

open science | open minds

\section{InTech Europe}

University Campus STeP Ri

Slavka Krautzeka 83/A

51000 Rijeka, Croatia

Phone: +385 (51) 770447

Fax: +385 (51) 686166

www.intechopen.com

\section{InTech China}

Unit 405, Office Block, Hotel Equatorial Shanghai

No.65, Yan An Road (West), Shanghai, 200040, China

中国上海市延安西路65号上海国际贵都大饭店办公楼405单元

Phone: +86-21-62489820

Fax: $+86-21-62489821$ 
(C) 2011 The Author(s). Licensee IntechOpen. This is an open access article distributed under the terms of the Creative Commons Attribution 3.0 License, which permits unrestricted use, distribution, and reproduction in any medium, provided the original work is properly cited. 